\title{
Microbiological assessment and hazardous effect of ready-to-eat foods presented for sale in Lucknow City, India
}

\author{
Suman Upadhyaya*, Purnima Srivastava, Ram Chandra and Naveen Arora \\ Department of Environmental Microbiology, BabaSaheb BhimRao Ambedkar University, Vidya Vihar, Rae Bareli Road, \\ Lucknow, 226025, Uttar Pradesh, India.
}

Received 21 June, 2017; Accepted 31 July, 2017

\begin{abstract}
Street foods play an important role in people's daily food options and their regular nutritional requirements are dependent on these foods, as their ever-growing busy schedule take away the opportunity to eat homemade food. Over the years, many food-borne diseases were reported due to contaminated non-homemade food consumption. This study was conducted to analyze the microbiological quality of foods which are sold on street side. Five most commonly consumed food items (samosa, chole, Panipuri, sandwich and momos) of street side carts of Lucknow City were tested. Escherichia coli, Pseudomonas aeruginosa, Klebsiella, Staphylococcus aureus like pathogenic organisms were found to be present in the five food items studied. Aantibiotic sensitivity test was carried out and E. coli was found to be resistant to Itranadozole and Rifampicin. Klebsiella was found to be resistant to Rifampicin. S. aureus was found to be sensitive to all the antibiotics tested (Rifampicin, Vancomycin, Tetracycline and Streptomycin). The study further highlights the level of microbial load found in various available street foods. The microbial load was found to be highest in sandwich then panipuri followed by momos and comparatively less in chole and samosa.
\end{abstract}

Key words: Microbiological, assessment, hazardous, ready-to-eat food.

\section{INTRODUCTION}

Ready-to-eat foods are foods that can be bought directly from street vendors or hawkers or at local markets and eaten immediately without necessarily having to cook before consumption as they have been already prepared by the vendors. Street foods are defined as "ready to eat foods and beverages prepared and or sold by vendors and hawkers especially in street and other similar public places" (FAO, 1987). These are very popular worldwide

\footnotetext{
*Corresponding author. E-mail: upadhyayasuman@gmail.com.
} 
and provide readily available delicacies at a cheaper rate. However, the unhygienic conditions in which these foods are prepared, stored and served raise a question regarding their microbiological quality. These foods can endanger public health by causing various acute and chronic food borne diseases through pathogenic microbes or toxic substances present in them. Despite the economic and nutritional benefits of street foods, the consumption of these roadside foods has been suggested to potentially increase the risk of food borne diseases as street foods are readily contaminated from different sources (Tambekar et al., 2008). In fact, street foods have often been associated with travellers' diarrhea and other foodborne diseases. The presence of Escherichia coli, Shigella dysenteriae, Streptococcus sp, Klebsiella, and Enterobacter suggested fecal contamination. Although some E. coli are harmless, Enterohaemorrhagic E. coli (EHEC) are capable of producing one or more toxin and a particular serotype O157:H7 have been associated with haemorrhagic colitis, haemolytic uraemic syndrome and thrombotic thrombocytopaenic purpura. Also Enterotoxigenic E. coli (ETEC) is associated with traveler's diarrhea. Similarly, Shigella dysenteriae have been associated with severe bacillary dysenteriae, while Streptococcus $\mathrm{sp}$, have been frequently associated with acute sore throat (Adams and Moss, 2008).

During the last few decades, the street food sector has expanded rapidly in urban areas of low and middleincome groups, both in terms of providing access to a diversity of inexpensive foods for low- income households and in offering job opportunities for many urban residents. The street food sector also contributes to the economy of an urban and pre-urban agricultural sector. In India, the National Policy for Urban Street Vendors/Hawkers stated that street vendors constitute approximately $2 \%$ of the population of a metropolis (Bhowmik, 2005). Due to its low cost and convenience, an estimated 2.5 billion people worldwide consume street food each day. Most of the studies done on street foods in India and abroad had indicated that these foods are not meeting the microbiological standards and are contaminated with various pathogens viz. E. coli, Vibrio, Salmonella, Listeria etc. (Chiou et al., 1996; Ryu et al., 1998; Mosupye and von Holy, 1999; Fang et al., 2003; Lewis et al., 2006). Sandeep et.al, 2005 reviewed the food borne illnesses associated with the consumption of street foods. These food borne illnesses were leading cause of morbidity and mortality worldwide (Bryan, 1988). The microbiological status of the food has been reported to be dependent on several factors like quality of raw material (Jones et al., 1991; Thunberg et al., 2002), handling and processing of food (Jones et al., 1991), microorganisms that survive the preservation and storage treatment (Gimenez and Salgaard 2004), and post process contamination (Long et al., 2002; Meena et al.,
2004). Beside direct health consequences, these food borne illnesses can reduce the productivity and economic output, and also impose substantial stress on health care system (Martins and Anelich, 2000; Mosupye and von Holy, 2000). Identification of precise sources of microbial contamination is crucial when devising strategies to reduce further outbreaks. The present study was therefore undertaken to evaluate the microbial quality and safety of consumption of different street foods sold in Lucknow Markets. The objectives of this study therefore are to isolate and characterize some bacterial pathogens from street vended food and to evaluate the antibiotic susceptibility profile.

\section{MATERIALS AND METHODS}

Five samples of street foods collected during February to April from different places of Lucknow City are as follows:

1. Panipuri from Utrathia Market

2. Chhole from Hazratganj market

3. Sandwich from BBAU canteen

4. Samosa from CharbaghLucknow

5. Momos from Rajnikhand market

\section{Sample collection}

The five street food samples were collected in the month of February and March 2016. Samples were collected in sterile bags for solid and semi-solid foods and in bottles for liquid food items from the market. It was carried with the consumer survey in which 100 subjects were taken regarding their commonly consumed street food. Five locations in Lucknow were chosen for the collection of samples, where the sale was maximum per day. Food samples (samosa, panipuri, sandwich, vegetarian momos and chole) were collected twice from local street shops and franchise's outlets at one month interval. All the samples were aseptically collected in sterile containers, stored at $4^{\circ} \mathrm{C}$ and analyzed within an hour of collection.

\section{Isolation and enumeration of microorganisms}

All the samples were aseptically collected in sterile containers, stored at $4^{\circ} \mathrm{C}$. Ten gram of sample was weighted under aseptic condition and properly homogenized by using a sterile pestle and mortar. Ten gram of homogenated sample was added to $90 \mathrm{ml}$ of sterile $0.85 \%$ saline water in a test tube and diluted serially upto 10 ${ }^{5}$ dilution was obtained. For bacterial isolation $0.1 \mathrm{ml}$ of dilution from each tube was aseptically pipette out and plate onto different nutrient agar media using spread plate technique. The plating was done in the laminar flow to maintain aseptic conditions. All the plates were placed in an incubator at $37^{\circ} \mathrm{C}$ for 24 to $48 \mathrm{~h}$ in an inverted position. For bacterial enumeration the plates were used to determine the number of colony forming units (CFU) per gram of food.

Nutrient agar, Mac-conkey agar, EMB agar, Manitol salt agar and Salmonella-Shigella agar were inoculated for total aerobic plate counts (total heterotrophic counts, coliform bacterial counts and total Salmonella shigella counts, respectively. Enumeration of bacteria and isolation of bacterial colonies was done after incubation 
Table 1. Microbial load of different street foods.

\begin{tabular}{lccc}
\hline Sample & Dilution factor & No. of colonies & CFU/ml \\
\hline Panipuri & $10^{-1}$ & 112 & $1.12 \times 10^{3}$ \\
Sandwich & $10^{-1}$ & 206 & $2.06 \times 10^{3}$ \\
Samosa & $10^{-1}$ & 28 & $2.8 \times 10^{2}$ \\
Momos & $10^{-1}$ & 37 & $3.7 \times 10^{2}$ \\
Chola & $10-1$ & 35 & $3.5 \times 10^{2}$ \\
\hline
\end{tabular}

Table 2. Organisms isolated from different street food.

\begin{tabular}{ll}
\hline Sandwich & Klebsiella \\
Panipuri & E. coli \\
Momos & Staphylococcus aureus \\
Chola & Pseudomonas aeruginosa \\
Samosa & Klebsiella \\
\hline
\end{tabular}

of plates at $37^{\circ} \mathrm{C}$ for $24 \mathrm{~h}$ to obtain viable bacterial colonies. Plates containing 30 to 300 colonies were selected and counted at the expiration of the incubation period using the colony counter (Gallenkamp, England). Bacterial counts were expressed as colony - forming units per gram of food sample (cfu/g).

\section{Morphological identification of isolates}

The identification of distinct bacterial colonies was based on standard methods (Cowan and Steel, 1985; Speck, 1976). The bacteria isolated were gram stained and specific biochemical tests were performed. The morphological characterization of each of the isolated colonies was done by observing their shape, colour, texture and appearance. The following biochemical test were performed on the isolates; sugars fermentation, catalase activity, oxidase test, methyl red, citrate utilization, coagulase activity and motility test (Buchansa and Gibbons, 1994).

\section{Antibiotic sensitivity test}

A single colony of the purified isolates was inoculated in $5 \mathrm{ml}$ sterile peptone water and incubated at $37^{\circ} \mathrm{C}$ overnight. Then a loopfull culture was diluted in $5 \mathrm{ml}$ sterile phosphate buffered saline and seeded into Muller Hinton agar. Antibiotic disc (Hi-Media) was placed on the surface of agar and incubated overnight at $37^{\circ} \mathrm{C}$. Zone of inhibition was recorded. A control sensitive culture was included in the experiment. The test determines the susceptibility of a microbial species against different antibiotic agents (Baur, 1966; Acharya, 2012).

\section{RESULTS AND DISCUSSION}

\section{Microbiological analysis}

The result depicted in Table 1 shows that the microbial load was highest in sandwich then panipuri followed by momos and comparatively less in chole and samosa because the samosa and chola gets the heat treatment and spices are added which have an antimicrobial property which reduces the microbial load. To prevent the occurrence of foodborne illnesses, it is important to ensure that foods sold are safe and hygienic. Total plate count was used to measure the general bacteria load of the food sampled and is useful tool in monitoring food process and the results may reflect the hygienic level of food handling and retail storage (Collins et al., 1989). Most of the studies done on street foods in India and abroad had indicated that these foods are not meeting the microbiological standards and are contaminated with various pathogens viz. E. coli, Vibrio, Salmonella, Listeria etc. The microbiological status of the food has been reported to be dependent on several factors like quality of raw material (Jones et al., 1991; Thunberg et al., 2002), handling and processing of food (Jones et al., 1991), microorganisms that survive the preservation and storage treatment (Gimenez and Salgaard 2004), and post process contamination (Long et al., 2002; Meena et al., 2004).

Gram negative rods and Gram positive cooci's were present in significant numbers in five street foods (panipuri, chhole, sandwich, samosa and momos). A total of eleven (5) organisms were isolated from street food; $E$. coli was isolated from panipuri, $P$. aeruginosa was isolated from chole, Klebsiella was isolated from Sandwich and Samosa and S. aureus was isolated from momos (Table 2). The isolates were differentiated on the basis of the cultural and cellular morphological studies, after which they were subjected to various biochemical and physiological test and the isolates were identified. Coliform bacteria are mainly found in water, soil and feacal matter. They are widely distributed in water, soil and vegetation (Rompre et al., 2002). The presence of coliforms in ready to eat food such as vegetable salad, packaged fried rice and egg burger depicts a deplorable state of hygiene and sanitary practices employed during the preparation and packaging of these street foods (Jay, 2005). Coliforms are indication of unsanitary conditions, unhygienic practices during and after production and poor source of water used (Beuchat, 1995). Muinde and Kuria (2005) reported that water used for preparation of street 


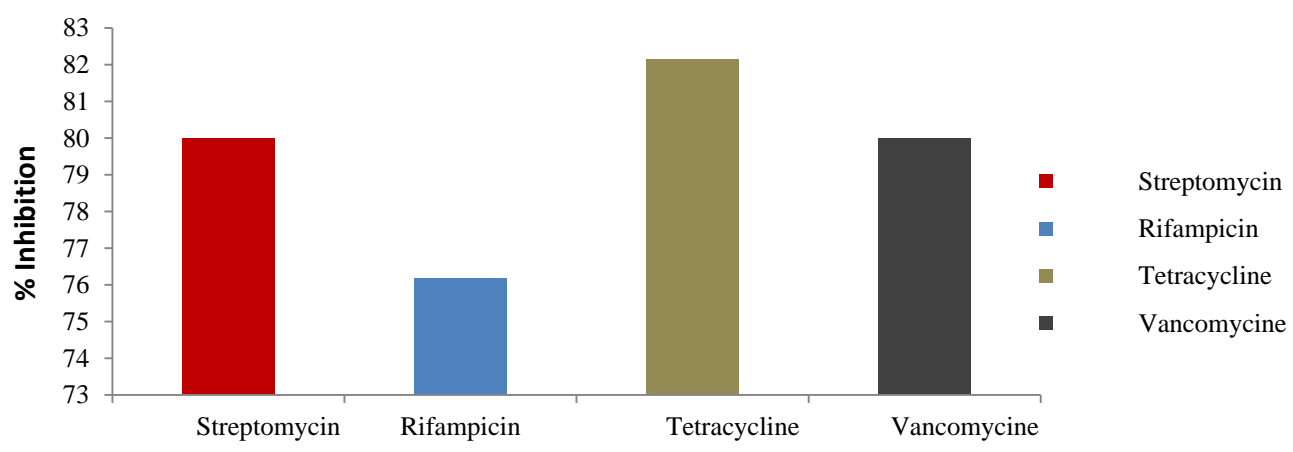

Figure 1. \%Inhibition zone against E. coli.

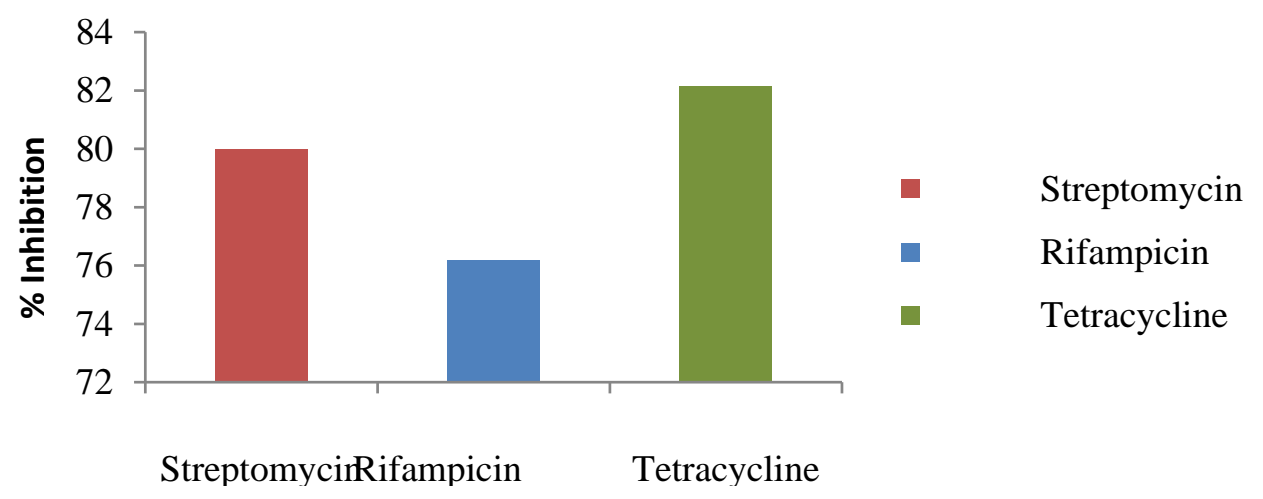

Figure 2. \%Inhibition zone of $P$. aeruginosa.

foods is often from sources that are not treated and lead to high bacterial count. The vegetables used in the preparation of the vegetable salad and fried rice always have contact with soil and if not properly washed with clean water could pose a high risk for street food consumers.

The presence of E. coli, Shigella dysenteriae, Streptococcus sp, Klebsiella, and Enterobacter represent fecal contamination. Some E. coli are harmless, however Enterotoxigenic E. coli (ETEC) is associated with traveler's diarrhea. Similarly, $S$. dysenteriae have been associated with severe bacillary dysenteriae, while Streptococcus $\mathrm{sp}$, have been frequently associated with acute sore throat (Adams and Moss, 2008). Due to washing of vegetables with contaminated water, it gets contaminated with Salmonella spp. Also pathogenic microorganisms are scatter through vegetables handling by infected workers, vendors and consumers in the market place. Hazard Analysis of Critical Control Point system (HACCP) study revealed that raw vegetables themselves carried pathogens and since they were not washed they continued to be present at the time of consumption. Sabbithi et al. (2014). Rather, the vendors should be sensitized and also issued some certificates so that they could be trusted and allowed to operate their business.

\section{Antibiotic susceptibility of all the isolated organisms determined by agar diffusion method}

E. coli was sensitive (S) to Chloramphenicol and Streptomycin and Resistant $(\mathrm{R})$ to Itranadozole and Rifampicin and Zone of Inhibition of Chloramphenicol was higher than Streptomycin (Figure 1). In case of $P$. aeruginosa, Streptomycin higher Zone of Inhibition was observed as compared with Rifampicin, and Itranadozole was found to be Resistant (Figure 2). Klebsiella isolated from sandwich was Sensitive to Streptomycin, Chloramphenicol and Tetracycline but the Zone of Inhibition of Tetracycline was too low as $16.6 \%$ and higher Zone of Inhibition was detected in case of Streptomycin as $72 \%$. No zone of inhibition (R) was observed in case of Rifampicin (Figure 3). In case of Klebsiella strain isolated from samosa, Streptomycin and Chloramphenicol gave higher Zone of Inhibition than Itranadozole. The strain was found to be Resistant to Rifampicin. The zone of inhibition of Streptomycin, 


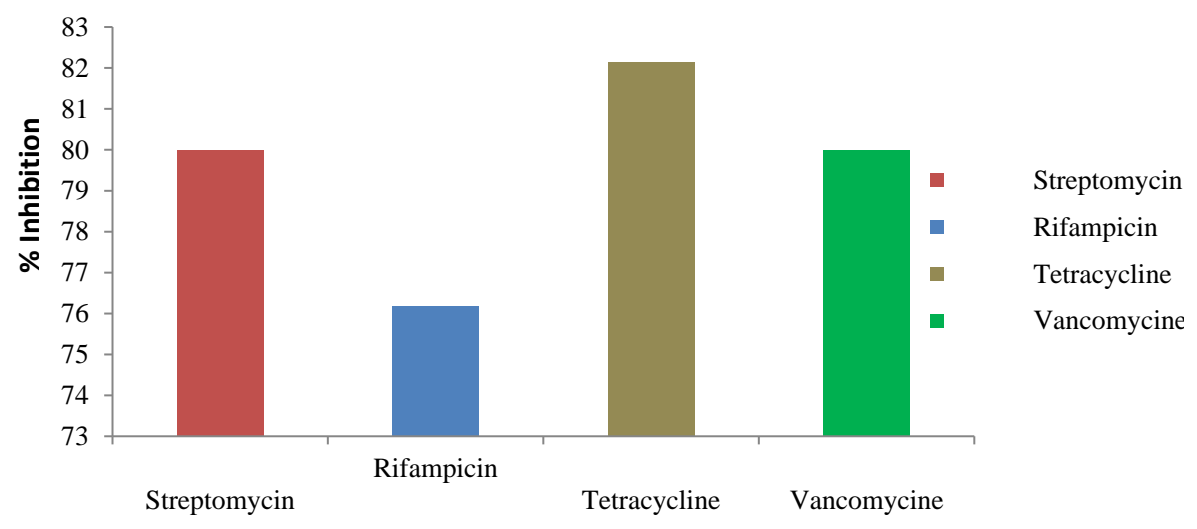

Figure 3. \%Inhibition zone of Klebsiella.

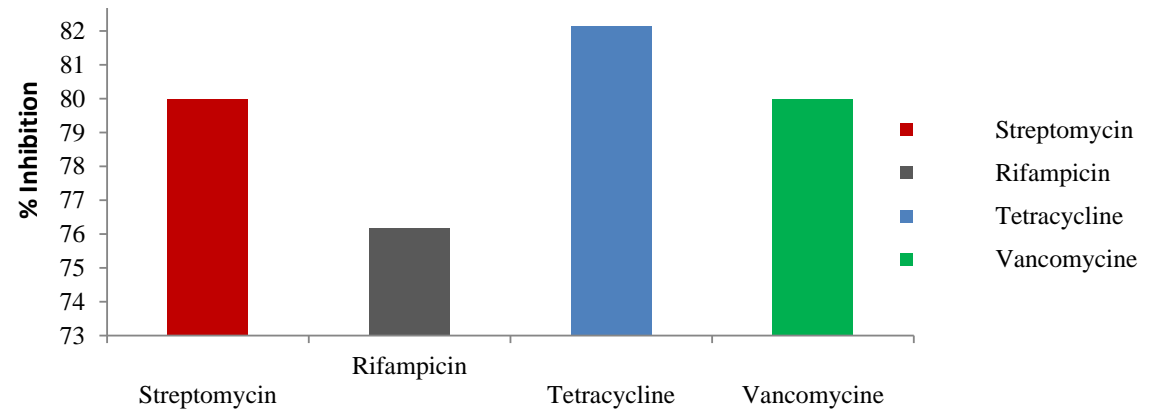

Figure 4. \% Inhibition zone of $S$. aureus.

Chloramphenicol and Itranadozole was $68.75,67.74$ and $28 \%$. S. aureus was found to be sensitive (S) to Rifampicin, Vancomycin, Tetracycline and Streptomycin (Figure 4). The organisms which were found to be pathogenic, E. coli, P. aeruginosa, Klebsiella, and S. aureus were tested for antibiotic sensitivity and these organisms showed resistant to different Antibiotics tested which can have serious health hazard and can pose problem in antibiotic therapy. Food contamination with antibiotic resistant bacteria can be a major threat to public health, as the antibiotic resistance determinants can be transferred to other pathogenic bacteria potentially compromising the treatment of severe bacterial infections. The prevalence of antimicrobial resistance among food borne has increased during recent decades (Chui et al., 2002; Davis et al., 1999). The use of antibiotic(s) after the intake of the organism(s) may not be effective as the organisms maybe susceptible or resistant to it. Resistance to antibiotics in food borne pathogens may create problems for disease or illness treatment while antibiotic susceptibility leads to healing of the illness which the organism(s) caused. Traveler's diarrhea is a major inconvenience to visitors arriving in developing
Countries from more industrialized areas (Dupont et al., 1982). Earlier studies were also been shown that antibiotic susceptibility results indicated 53.85\% resistance and $46.15 \%$ sensitivity among vended food isolates. The prevalence of antimicrobial resistance among foodborne pathogens has increased during recent decades (Boonmar et al., 1998a, b; Chui et al., 2002; Davis et al., 1999; Threfall et al., 2000), possibly as a result of selection pressure created by the use of antimicrobials in food-producing animals (Aarestrup, 1999; Angulo et al., 2000; Bywater, 2004; Teuber, 2001; Van den Bogaard and Stobberingh, 2000). The coexistence of resistance genes with mobile elements such as plasmids, transposons and integrons facilitates the rapid spread of antibiotic resistance genes among bacteria (Sunde, 2005). Also, high rates to antibiotics resistance of bacteria may possibly resulted from inappropriate or uncontrolled use of antibiotics in farming practices, so it is necessary to pay more attention to food hygiene practices to reduce or eliminate the risk from antibiotic resistance and pathogenic bacteria originating from food. In addition, the use of antibiotics in animal feeds need to be regulated strongly to minimize the 
opportunity for organisms to develop resistance (Van et al., 2007). The result of this study demonstrated that the food samples vended for consumer consumptions were contaminated by pathogenic bacteria which if ingested may be deleterious to consumers' health and may lead to food borne illness or disease.

\section{Conclusion}

Gram negative rods and gram positive cooci's were present in significant numbers in five street foods. Hence this study has clearly demonstrated that some of the most popular types of foods (panipuri, chhole, sandwich, samosa and momos) that were vended on the streets of Lucknow City do not meet the required acceptable quality and safety levels. Measures need to be taken to ensure that street vendor food ingredients should be produced and stored hygienically at appropriate temperatures and well protected from flies, dust, wind, and all sources of contamination. Utensils should be washed using detergents and clean hot water. The results of this study have illustrated the extent of antibiotic resistance in all the isolated organisms found. It is necessary to pay more attention to food hygiene practices to reduce or eliminate the risk from food borne pathogens; especially those that are originated from street food. Also, strict implementation of food sanitation code and license for street food vendors is needed to make the consumers save. If possible, public health authorities should intensify efforts to monitor conditions of sanitation and hygiene in establishment serving food and drink to the public. So, food safety education is a critical part of the overall strategy to reduce the incidence of food borne illness and complements regulatory and other activities. However, meeting the huge challenge of food safety in the $21^{\text {st }}$ Century will require the application of new methods to identify, monitor and access food borne hazard. Both traditional and new technologies for assuring food safety should be improved and fully exploited. This need to be done through legislative measures where suitable, but much greater reliance on voluntary compliance and education of consumers and professional food handlers. Finally, it is necessary for public health organizations to be concerned since microorganisms causing food borne hazards and food spoilage can be isolated from raw materials and finished products; thus reduction of contamination is an achievable policy objective. It is necessary to pay more attention to food hygiene to reduce or eliminate the risk from food borne pathogens; especially those that are originated from street food. Also, strict implementation of food sanitation code and license for street food vendors is needed to make the consumers save. If possible, public health authorities should intensify efforts to monitor conditions of sanitation and hygiene in establishment serving food to the public.

\section{CONFLICT OF INTERESTS}

The authors have not declared any conflict of interests.

\section{REFERENCES}

Aarestrup FM (1999). Association between the consumption of antimicrobial agents in animal husbandry and the occurrence of resistant bacteria among food animals. Int. J. Antimicrobiol. Agents 12:279-285.

Acharya A, Nepal HP, Gautam R, Shrestha S (2012). Enteric fever pathogens and their antimicrobial susceptibility pattern in Chitwan. J. Chitwan Med. Coll. 1:26-30.

Adams MR, Moss MO (2008). Bacterial agents of foodborne illness in food microbiology third edition. The royal society of chemistry, Cambridge UK. pp. 182-269.

Angulo FJ, Johnson KR, Tauxe RV, Cohen ML (2000). Origins and consequences of antimicrobial-resistant nontyphoidal Salmonella: implications for the use of fluoroquinolones in food animals. Microb. Drug Resist. 6:77-83.

Baur AW (1966). Antibiotic susceptibility testing by a standardized single disk method. Am. J. Clin. Pathol. 45:493-496.

Beuchat J (1995). Pathogenic microorganism associated with produce. J. Food Prot. 59:204-216.

Bhowmik SK (2005). Street vendors in Asia: A review. Econ. Political Weekly 4:2256-2264.

Boonmar S, BagtraKulnonth A, Pornninangwong S (1998a). Predominate servovars of Salmonella in humans and foods from Thailand. J. Med. Sci. 60:877-880.

Boonmar S, Bangtrakulnonth A, Pornruangwong S, Samosornsuk S, Kaneko K, Ogawa M (1998b). Significant increase in antibiotic resistance of Salmonella isolates from human being and chicken meat in Thailand. Vet. Microbiol. 62:73-80.

Bryan FL, Michanie SC, Alvarez P, Paniagua A (1988). Critical control points of street vended foods in Dominican Republic. J. Food Prot. 51:373-383.

Buchansa RE, Gibbons NE (1994). Bergy's Manual of Determinative Bacteriology, 9th Edition. The Williamsn and Wilkins company, Baltimore, 39 - 596.

Bywater RJ (2004). Veterinary use of antimicrobials and emergence of resistance in zoonotic and sentinel bacteria in the EU. J. Vet. Med. 51:361-363.

Chiou TY, Wang MY, Lin AY (1996). Sanitary indicator bacteria of the hot-keeping cooked food items in Southern Taiwan. Food Sci. 23:909-912.

Chiou TY, Wang MY, Lin AY (1996). Sanitary indicator bacteria of the hot-keeping cooked food items in Southern Taiwan. Food Sci. 23:909-912.

Collins CR, Lynes PM, Grange JM (1989). Microbiological Methods.6th edition. Butterworth \& Co (publishers) Ltd.

Chui CH, Wu TL, L.H. Su LH, Chu C, Chia JH, Kuo AJ, Chien MS, Lin TY (2002). The emergence in Taiwan of fluoroquinelone resistance in Salmonella enterica serotype cholerasuls. N. Engl. J. Med. 346:416419.

Cowan ST, Steel KJ (1985). Manual for the Identification of Medical Bacterial Cambridge University Press, Cambridge.

Davis MA, Hancock DD, Besser DH, Rice JM, Gay CG, Geerhart L, DiGiacomo $R$ (1999). Changes in antimicrobial resistance among Salmonella entericaserovar. Infect. Des. 5:802-806.

Dupont HL, Evans DJ, Rios N, Cabuda FT, Evans DJ, Dupont MW, (1982). Prevention of travler's diarrhea with trimethoprim sulfamethoxazole. Rev. Infect. Dis. 41: 533-539.

Fang TJ, Que-king W, Chia-wei L, Min-Ju H, Tzu-Hui W, (2003). Microbiological quality of $18^{\circ} \mathrm{C}$ ready to eat food products sold in Taiwan. Int. J. Food Microbiol. 80:241-250.

Food Agriculture Organization (FAO) (1987). Street Foods. Report of an FAO technical meeting on street foods Calcutta India, 6-9 Nov. 1995. FAO Food and Nutrition Paper 63, Rome. 
Gimenez BC, Salgaard P (2004). Modeling and Predictive the simultaneous growth of Listeria Monocytogenes and spoilage microorganisms in cold-smoked salmon. J. Appl. Microbial. 96:96109.

Jay MJ (2005). Modern Food Microbiology 4th Ed, Chapman and Hall, New York, 187p.

Jones FT, Axtell RC, Rives DV, Scheideler SE, Tarver FR, Walker RL, Wineland MJ (1991). A Survey of Campylobacter jejuni contamination in modern broiler production and processing systems. J. Food Prod. 54:259-262.

Lewis JE, Thompson P, Rao BN, kalavate C, Rajanna B (2006). Human bacteria in street vended fruit Juices; A case study of Visakhapatnam city, India. Internet J. Food Saf. 8:35-38.

Long SM, Adak GK, O'Beirne SJ, Gillesple IA (2002). General Outbreaks of infectious intestinal disease linked with salad vegetables and fruits, England and Wales. 1992-2000, Communicable Disease Public Health 5:101-105.

Martins JM, Anelich LE (2000). Socio-economic features of street vending, hygiene and microbiological status of street foods in Gauteng, 2000, Technical Cooperation Programme (TCP) Project on Improving Street Foods in South Africa.

Mena C, Almeida G, Carneiro L, Teixeira P, Hogg T, Gibbs PA (2004). Incidence of Listeria monocytogenes in different food products commercialized in Portugal. Food microbiology. 21(2):213-216.

Mosupye FM, Von Holy A (1999). Microbiological quality and safety of ready-to-eat street-vended foods in Johannesburg, S Afr. J. Food Prot. 62(11):1278-1284.

Mosupye FM, Von Holy A (2000). Microbiological hazard identification and exposure assessment of street food vending in Johannesburg, South Africa. Int. J. Food Microbiol. 61:137-145.

Muinde OK, Kuria E (2005). Hygienic and sanitary practices of vendors of street foods in Nairobi, Kenya. Afr. J. Food Agric. Nutr. Dev. 5:114.

Rompre A, Servais P, Baudart J, De-Roubin M, Laurent P (2002). Detection and enumeration of coliforms in drinking water: Current methods and emerging approaches. J. Microbiol. Methods 49:31-54.

Ryu JH, Beuchat LR (1998). Influence of acid tolerance responses of survival, growth, and cross protection of $E$. coli $0157: \mathrm{H} 7$ in acidified media and fruit juices. International J. Food Microbiol. 45:185-193.

Sabbithi A, Kumar RN, Kashinath L, Bhaskar V, Rao VS (2014). Microbiological quality of salads served along with street foods of Hyderabad, India. Int. J. Microbiol. ID 932191.

Sunde M, Norstro M (2005). The genetic background for streptomycin resistance in Escherichia coli influences the distribution of MICs. J. Anti- microb. Chemother. 55:87-90.

Speck ML (1976). Compendium of Methods for Microbiological Examination of Foods. America Public Health Association, Washington D.C. pp. 277-327.

Tambekar DH, Jaiswal V, Dhanorkar D, Gulhane P, Dudhane M. (2008). Identification of Microbiological hazards and Safety of readyto-eat food vended streets of Amravati City, India. J. Appl. Biosci. 7:195-201.
Teuber M (2001). Veterinary use and antibiotic resistance. Curr. Opin. Microbiol. 4:493-499.

Threfall EJ, Ward LR, Frost JA, Willshaw GA (2000). The emergence and spread of antibiotic resistance in foodborne bacteria. Int. J. Food Microbiol. 62:1-5.

Thunberg RL, Tran Bennett RW, Matthews RN, Belay N (2002). Microbial evaluation of selected fresh produce obtained at retail market. J. Food Prot. 65:677-682.

Van TTH, George M, Istivan T, Tran L, Coloe PJ (2007). "Antibiotic Resistance in Food-Borne Bacteria Contaminants in Vietnam",Appl. Einviron. Microbiol. 73(12):7906-7911.

Van den Bogaard AE, Stobberingh EE (2000). Epidemiology of resistance to antibiotics. Links between animals and humans. Int. J. Antimicrob. Agents 14:327-335. 